\title{
Physicochemical properties and origin of organic groups detected in boreal forest using an aerosol mass spectrometer
}

\author{
T. Raatikainen ${ }^{1}$, P. Vaattovaara ${ }^{2}$, P. Tiitta ${ }^{2}$, P. Miettinen ${ }^{2}$, J. Rautiainen ${ }^{3}$, M. Ehn ${ }^{4}$, M. Kulmala ${ }^{4}$, A. Laaksonen ${ }^{1,2}$, \\ and D. R. Worsnop ${ }^{1,2,4,5}$ \\ ${ }^{1}$ Finnish Meteorological Institute, P.O. Box 503, 00101 Helsinki, Finland \\ ${ }^{2}$ Department of Physics and Mathematics, University of Eastern Finland, P.O. Box 1627, 70211 Kuopio, Finland \\ ${ }^{3}$ Department of Chemistry, P.O. Box 55, 00014 University of Helsinki, Finland \\ ${ }^{4}$ Division of Atmospheric Sciences, Department of Physics, P.O. Box 64, 00014 University of Helsinki, Finland \\ ${ }^{5}$ Aerodyne Research Inc., 45 Manning Road, Billerica, Massachusetts, USA
}

Received: 18 September 2009 - Published in Atmos. Chem. Phys. Discuss.: 19 October 2009

Revised: 1 February 2010 - Accepted: 11 February 2010 - Published: 23 February 2010

\begin{abstract}
An Aerodyne quadrupole aerosol mass spectrometer (Q-AMS) was deployed in Hyytiälä, a forested rural measurement site in southern Finland, during a 2-week measurement campaign in spring 2005. Q-AMS measures mass concentrations of non-refractory species including sulphate, nitrate, ammonium and organics from submicron particles. A positive matrix factorization method was used in identifying two oxygenated organic aerosol (OOA) groups from the measured total organic mass. The properties of these groups were estimated from their diurnal concentration cycles and correlations with additional data such as air mass history, particle number size distributions, hygroscopic and ethanol growth factors and particle volatility. It was found that the aged and highly oxidized background organic aerosol (OOA1 or LV-OOA) species have a wide range of hygroscopic growth factors and volatilization temperatures, but on the average OOA1 is the less volatile and more hygroscopic organic group. Hygroscopic properties and volatilities of the OOA1 species are correlated so that the less volatile species have higher hygroscopic growth factors. The other, less oxidized organic aerosol group (OOA2 or SV-OOA) is more volatile and non-hygroscopic. Trajectory analysis showed that OOA1 and the inorganic species are mainly long-range transported anthropogenic pollutions. OOA2 species and its precursor gases have short atmospheric life times, so they are from local sources. These results span the range of pre-
\end{abstract}

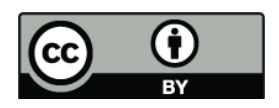

Correspondence to: T. Raatikainen (tomi.raatikainen@fmi.fi) vious observations of oxygen content, volatility and hygroscopic growth factor, simultaneously coupling all three measurements for the first time.

\section{Introduction}

Organic species have different chemical and physical properties and they constitute a significant fraction of submicron $\left(\mathrm{PM}_{1}\right)$ continental aerosol particle mass (Saxena and Hildemann, 1996). Therefore, they have a significant effect on aerosol properties (e.g. hygroscopicity, particle growth and cloud droplet activation) and ultimately on the global climate.

The main inorganic species (sulphate, nitrate and ammonium) can be characterized rather easily from submicron particles, but the organic fraction is a mixture of thousands of different species with low concentrations. Some of the organic species can be identified, for example, by analyzing filter samples (Anttila et al., 2005a,b), but usually the identified mass is only a small fraction of the total organic mass. Even if individual species have low concentrations, they may be important when considered as a group of similar species.

The Aerodyne Aerosol Mass Spectrometer (AMS) is able to detect non-refractory species such as ammonium, sulphate, nitrate and organics in submicron particles at about 10 min time resolution (Jimenez et al., 2003; Canagaratna et al., 2007). For organic analysis, individual species cannot be identified within the measured total non-refractory mass loading. However, custom principal component analysis

Published by Copernicus Publications on behalf of the European Geosciences Union. 
(CPCA) (Zhang et al., 2005), multiple component analysis (MCA) (Zhang et al., 2007) and more recently positive matrix factorization (PMF) (Lanz et al., 2007; Ulbrich et al., 2009) have been used in identifying organic groups within total organic mass. More and less oxidized oxygenated (OOA, types 1 and 2) and hydrocarbon-like (HOA) organic aerosols are examples of typical organic groups (Lanz et al., 2007; Ulbrich et al., 2009). Recently OOA1 and OOA2 have been called (low-volatility) LV-OOA and (semi-volatile) SVOOA, respectively (Jimenez et al., 2009).

Organic aerosol groups are not well-defined chemical substances having an exact mass and molecular formula, but complex mixtures of organic compounds described by average properties. The exact mixtures making up OOA 1 and OOA2 are likely to vary temporally and spatially; however, large differences in the AMS signatures or in the properties of the groups have not been seen in the AMS measurements conducted around the world (Ng et al., 2009). Therefore, these organic groups are becoming common representatives of the aerosol organic fraction (Jimenez et al., 2009).

A quadrupole AMS from the University of Kuopio was one of the instruments used in the intensive spring 2005 measurement campaign in Hyytiälä, which is a rural measurement site in southern Finland. Additional information about the campaign can be found from related publications such as Eerdekens et al. (2009); Kulmala et al. (2008); Riipinen et al. (2007); Ehn et al. (2007b). Hyytiälä represents continental background boreal forest where a significant fraction of particle mass is organic (Kulmala et al., 2001). Previously, Hyytiälä aerosol composition has been measured directly, for example, by Q-AMS (Allan et al., 2006) and by analyzing filter samples (Cavalli et al., 2006; Anttila et al., 2005a,b; Kourtchev et al., 2005; Mäkelä et al., 2001). Aerosol composition can be inferred from measured particle properties such as hygroscopicity, ethanol affinity and volatility (Kulmala et al., 2007; Boy et al., 2004; Hämeri et al., 2001; Ehn et al., 2007b; O'Dowd et al., 2000).

Filter sample analysis (Saarikoski et al., 2005; Niemi et al., 2006) have identified $80 \%$ of the total Hyytiälä $\mathrm{PM}_{1}$ aerosol mass with ammonium sulphate (ca. $40 \%$ ) and organics (ca. 35\%) as the main components. The rest of the identified mass is mainly elemental carbon, nitrate, potassium and sea salt. With the exception of potassium and species from refractory material such as elemental carbon, metal oxides, fly ash, crustal material and sea salt, the AMS can detect the above mentioned species (Canagaratna et al., 2007).

Particle hygroscopicity and ethanol affinity can be described by growth factors, which are defined as a diameter of a droplet being in equilibrium with water or ethanol vapour, divided by the dry size. Previous studies (Hämeri et al., 2001; Boy et al., 2004; Petäjä et al., 2005; Ehn et al., 2007a) have shown that hygroscopic growth factors have a clear diurnal cycle in Hyytiälä so that they are highest during days and lowest during nights. This indicates that the fraction of less hygroscopic material such as organics is higher at night. Usually polar substances are soluble in polar solvents and insoluble in non-polar solvents. Because ethanol and water have different polarities, hygroscopic and ethanol growth factors are expected to have opposite trends, though sometimes this is not the case (Boy et al., 2004; Vaattovaara et al., 2009). Similarly to the growth factors, particle volatilities are based on size measurements before and after heating (O'Dowd et al., 2000; Ehn et al., 2007b). Commonly particulate species have a wide range of volatilization temperatures starting from highly volatile organics to non-volatile species such as sea salt and black carbon.

Growth factors as well as particle volatilities can be predicted when particle composition is measured and physical and chemical properties of the components are known (Aklilu et al., 2006; Varutbangkul et al., 2006; Gysel et al., 2004, 2007). Such analysis have been limited by poor knowledge of properties of the aerosol organic fraction, since organic species have diverse properties and their concentrations vary with time. Organic groups such as OOA1, OOA2 and HOA contain chemically and physically similar species, so it should be possible to describe their properties by average values. These could be then used in describing properties of the aerosol organic fraction.

Because properties of the inorganic species are generally well known, we will concentrate on the organic fraction. We will divide the organic fraction into two groups and estimate their average properties (e.g. hygroscopicity, ethanol affinity, volatility and origin) based on their mass spectra, correlation with measured growth factors and volatility, diurnal concentration variations and analysis of back trajectories.

\section{Measurements}

\subsection{The site}

Measurements were made at Hyytiälä SMEAR II (Station for Measuring Forest Ecosystem-Atmosphere Relation) site during spring 2005 BACCI (Biosphere-Aerosol-Cloud-Climate Interactions, Kulmala et al., 2008) and QUEST (Quantification of Aerosol Nucleation in the European Boundary Layer) campaigns. We will focus on time period from 31 March to 15 April 2005 when the AMS was operating. The site is described in Vesala et al. (1998), Kulmala et al. (2001) and Hari and Kulmala (2005). Briefly, Hyytiälä is a rural forested measurement site in southern Finland $\left(61^{\circ} 51^{\prime} \mathrm{N}, 24^{\circ} 17^{\prime} \mathrm{E}\right.$, $181 \mathrm{~m}$ above sea level), in the middle of the boreal forest belt. The closest major city is Tampere (population 204306 at the end of 2005) about $60 \mathrm{~km} \mathrm{S-SW} \mathrm{from} \mathrm{the} \mathrm{station.}$

The SMEAR II station has a number of continuously operated instruments for measuring, e.g., particle size distributions, gas phase concentrations and meteorology. In particular, size distributions of 3-1000 nm particles are measured by a twin Differential Mobility Particle Sizer (DMPS) system at about $10 \mathrm{~min}$ time resolution (Aalto et al., 2001). 


\subsection{Growth factors}

Two tandem differential mobility analyzers (TDMA) were measuring particle growth factors (GF), defined as droplet size after exposing a dry particle to a solvent vapour divided by the dry size. The hygroscopicity TDMA (HTDMA) measures growth factors in water vapour (Rader and McMurry, 1986; Hämeri et al., 2000; Ehn et al., 2007a) and the organic TDMA (OTDMA) uses ethanol vapour (Joutsensaari et al., 2001; Vaattovaara et al., 2005).

Both instruments have similar operating principles. Briefly, the first DMA selects a narrow size range from dried ambient particles (with RH less than 3\% and 15\% for the current OTDMA and HTDMA, respectively). These dried particles are then exposed to a solvent vapour and the resulting size distribution is measured by the second DMA and a condensation particle counter (CPC). Final size distributions can be much wider than the original ones and more than one particle mode can be present. The reported GF values are based on mean diameters describing average growth properties.

It is possible to vary solvent vapour saturation ratios, but in this case hygroscopic (HGF) and ethanol (EGF) growth factors were measured at about 88 and $82 \%$ saturation ratios, respectively. It is also possible to measure growth factors for different initial particle sizes starting from a few nanometres up to hundreds of nanometres. Because the TDMA instruments in this study are designed for ultrafine particles, the highest measured initial particle dry size was $50 \mathrm{~nm}$. Only the $50 \mathrm{~nm}$ data is used here as it is closest to the AMS size range.

EGF and HGF can be calculated for a known ideal dry particle as a function of solvent (subscript $s$ ) mole fraction $\left(x_{S}\right)$ :

$\mathrm{GF}^{3}=1+\frac{v_{s} \sum_{i} \xi_{i} v_{i} / v_{i}}{1 / x_{s}-1}$

$\xi_{i}, v_{i}$ and $v_{i}$ are dry particle volume fraction, dissociation fraction and molecular volume of species $i$, respectively. In practice, growth factors are measured as a function of solvent vapour equilibrium saturation ratio, which is a product of solvent activity coefficient, mole fraction and a curvature term depending on droplet size, surface tension, and size of the solvent molecule.

When solutes are expected to behave independently, their properties in Eq. (1) can be replaced by growth factors of pure components at the same solvent mole fraction. The resulting mixing rule based on the Zdanovskii-StokesRobinson (ZSR) equation (Stokes and Robinson, 1966) is:

$\mathrm{GF}^{3}=\sum_{i} \xi_{i} \mathrm{GF}_{i}^{3}$

Pure component growth factors are readily available for the common inorganic species, but not for atmospheric organics.

\subsection{Particle volatility}

The third tandem DMA instrument, the ultrafine volatility TDMA (VTDMA), measures particle size distribution after heating a narrow size range of dried $(\mathrm{RH}<3 \%)$ ambient particles to 50,150 and $280^{\circ} \mathrm{C}$ temperatures (Tiitta et al., 2010). The instrument setup is similar to the HTDMA and OTDMA setups, but instead of a humidifier, our VTDMA contains three parallel heating tubes, which can be selected by a computer controlled valve assembly. The residence time of the particles in the heating column is about $1.5 \mathrm{~s}$, which is enough for evaporating a narrow size range of ultrafine particles (Philippin et al., 2004; Villani et al., 2007). This was also confirmed in our laboratory experiments, which showed that results for mixed ammonium sulphate- $\alpha$-pinene particles were not dependent on residence time. Before the second DMA, there is a cooling section and an absorber tube containing activated carbon for removing evaporated vapours. Just as in the case of HGF and EGF measurements, volatilities were measured for different initial dry particle sizes, but only the $50 \mathrm{~nm}$ data is used here.

Size distributions of dried $50 \mathrm{~nm}$ particles heated to 50 , 150 and $280^{\circ} \mathrm{C}$ were measured successively within 20 or $30 \mathrm{~min}$. Because $50 \mathrm{~nm}$ was not the only initial size, one $50 \mathrm{~nm}$ temperature series was measured once in 60 or $90 \mathrm{~min}$. The reported time values are mean times of the successive 50, 150 and $280^{\circ} \mathrm{C}$ measurements for $50 \mathrm{~nm}$ particles.

Instead of calculating growth or shrink factors, we calculated volume fractions for particulate species evaporating at different temperature ranges. Volume fractions are based on average particle volumes (total particle volume divided by total particle number) calculated from the measured size distributions, which were corrected for size dependent transmission efficiency (Tiitta et al., 2010). Results showed negligible evaporation below $50^{\circ} \mathrm{C}$. For example, geometric mean diameters of particles heated to $50^{\circ} \mathrm{C}$ were from $47.4 \mathrm{~nm}$ to $51.1 \mathrm{~nm}$ with an average of $49.8 \mathrm{~nm}$, which is very close to the $50 \mathrm{~nm}$ initial size. Therefore, this lowest temperature range $\left(<50^{\circ} \mathrm{C}\right)$ was not included here; furthermore, because $50^{\circ} \mathrm{C}$ particles were sometimes larger than the initial $50 \mathrm{~nm}$ particles, $50^{\circ} \mathrm{C}$ average particle volumes were used as initial volumes. Volume fractions were then calculated for species evaporating at temperature ranges $50-150,150-280$ and $>280^{\circ} \mathrm{C}$.

This average particle volume approach is valid when particles do not evaporate completely at the measurement temperatures. For example, if some particles were completely evaporated at $200{ }^{\circ} \mathrm{C}, 280^{\circ} \mathrm{C}$ average particle volume would be overestimated. The validity of the approach was confirmed by correlating total particle number concentrations from the 50,150 and $280^{\circ} \mathrm{C}$ measurements. Unit slopes and near zero offsets of linear fits indicate no particles completely evaporate, in good agreement with the findings of Ehn et al. (2007b). 


\subsection{AMS}

The Aerodyne Quadrupole Aerosol Mass Spectrometer (QAMS or briefly just AMS) was placed in a measurement cottage close to the other instruments. The AMS measured mass concentrations of non-refractory $\mathrm{PM}_{1}$ aerosol species as a function of particle size at about $10 \mathrm{~min}$ time resolution. Here non-refractory refers to species detected via thermal vaporization at $\sim 600^{\circ} \mathrm{C}$ temperature. Therefore, the AMS can not detect black carbon (BC), sea salt or crustal material. Typically these species have low concentrations in the submicron continental background aerosol (Seinfeld and Pandis, 2006).

Thorough description of the instrument and data analysis are given elsewhere (Jayne et al., 2000; Allan et al., 2003, 2004; Jimenez et al., 2003; Alfarra et al., 2004; Canagaratna et al., 2007). Briefly, the AMS is composed of inlet, aerodynamic lens, sizing chamber, oven, ionization chamber and mass spectrometer. The sample flow rate is kept constant by a critical orifice. The particle beam is focused by the aerodynamic lens and most of the air is removed in a differentially pumped vacuum system. Due to the pressure drop at the exit of the lens, particles are accelerated depending on their size, density and shape. The sizing chamber contains a chopper, which is a movable rotating disc with two narrow slits. After traversing the sizing chamber, particles impact the oven, which is a porous tungsten block heated to about $600{ }^{\circ} \mathrm{C}$ temperature. Vaporized molecules are ionized by electron impact ionization $(70 \mathrm{eV})$ and positive ions are detected by the quadrupole mass spectrometer. Mass spectra (ions/s) are measured with unit mass per charge $(\mathrm{m} / \mathrm{z}$ ) resolution up to $300 \mathrm{~m} / \mathrm{z}$.

Usually two measurement modes, MS (mass spectrum) and PTOF (particle time of flight), are alternated during each time step. A full mass spectrum (ion signal as a function of $m / z$ ) is measured in the MS-mode. Based on known ion fragmentation patterns, air and inorganic species are easily separated within the measured spectrum; the remaining ions are largely from organics (Allan et al., 2004). Mass concentrations $\left(\mu \mathrm{g} / \mathrm{m}^{3}\right)$ are calculated from the ion signals by using measured air sample flow rate, nitrate ionization efficiency (IE), relative IE's of the other species (RIE) and collection efficiency. A default collection efficiency of 0.5 was used in our calculations. Based on expected charge balance between the detected cations $\left(\mathrm{NH}_{4}^{+}\right)$and anions $\left(\mathrm{SO}_{4}^{2-}, \mathrm{NO}_{3}^{-}\right.$ and $\mathrm{Cl}^{-}$), ammonium RIE was changed to 5.5 from the default value of 4 . It is quite common that ammonium RIE is adjusted, and in fact, common RIE values range from 3.5 up to 6.0 (Canagaratna et al., 2007). PTOF-mode can be used for measuring size dependent mass concentrations, but due to low mass concentrations, PTOF data was found to be too noisy for reliable analysis. Therefore, it is not used here.

There were some non-standard adjustments during the campaign. Detailed explanation is given in the supplementary material (http://www.atmos-chem-phys.net/10/ 2063/2010/acp-10-2063-2010-supplement.pdf). The oven temperature was changed from initial value of $610^{\circ} \mathrm{C}$ to $700^{\circ} \mathrm{C}$ on 5 April and finally to $750^{\circ} \mathrm{C}$ on 11 April. These changes had clear effects on signal noise levels and on some mass peaks (e.g. $m / z, 23$ and $41, \mathrm{Na}^{+}$and the ${ }^{41} \mathrm{~K}^{+}$). For this reason, organic $\mathrm{m} / \mathrm{z}, 41$ peaks were selected to be $80 \%$ of the organic $\mathrm{m} / \mathrm{z}, 43$ peaks. In addition to the oven temperature changes, aerodynamic lens was adjusted on 7 April. Compared to the total particle volume from DMPS measurements, AMS mass concentrations doubled after the lens adjustment. Because of these oven and lens adjustments, there is uncertainty in absolute mass concentrations. However, mass ratios and fractions are meaningful, since all mass concentrations are biased by the same factors.

\subsubsection{Positive matrix factorization}

In the case of organic aerosol mass spectrometry, the purpose of the component analysis techniques is to find timedependent concentrations and mass spectra for two or more organic groups (factors) so that their sum (predicted timedependent mass spectrum) would match the measured one. Positive matrix factorization (PMF) and component analysis techniques (Zhang et al., 2005, 2007) are similar methods for solving this problem, but constraints are used in the PMF method to get positive concentrations and spectra. The PMF Evaluation Tool (Ulbrich et al., 2009) based on version 4.2 of PMF2 algorithm (Paatero and Tapper, 1994; Paatero, 1997) was used in analysing current data. PMF2 was run in a robust mode for different rotational parameter (FPEAK) values from -1.5 to 1.5 and up to four factors. All other PMF2 parameters had their default values. Weak variables as well as $\mathrm{m} / \mathrm{z} 44$ related peaks were downweighted and a minimum error criteria was applied as described in Ulbrich et al. (2009). In addition to that, $\mathrm{m} / \mathrm{z} 41$ and 43 were downweighted by a factor of $\sqrt{2}$ as $m / z 41$ depends directly on $m / z$ 43. More details about the FMF analysis are given in the supplementary material (http://www.atmos-chem-phys. net/10/2063/2010/acp-10-2063-2010-supplement.pdf).

Calculations showed that only two distinct factors could be identified. Additional factors were merely noise or linear combinations of the two factors, or one factor was just split into two or more parts. Two-factor solutions seem to be somewhat sensitive to the rotational parameter FPEAK. Reasonable factors were found for FPEAK values from 0 to -0.3 , so the mean value i.e. solution with FPEAK $=-0.15$ was selected to be used in the calculations. In practice, these factors based on different FPEAK values have very similar concentration time series and only the $m / z 44$ peaks are different. Because our calculations are based on concentrations, results are not sensitive on FPEAK values. More details are given in the supplementary material (http://www.atmos-chem-phys.net/ 10/2063/2010/acp-10-2063-2010-supplement.pdf). 


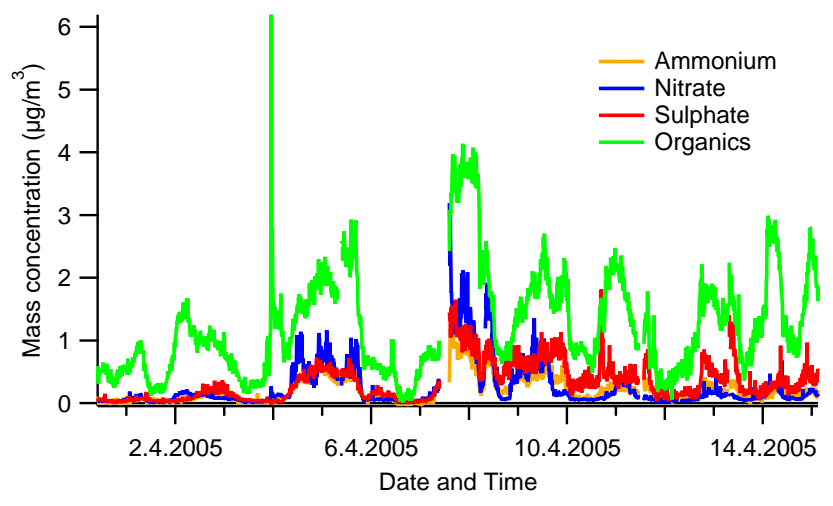

Fig. 1. Mass concentrations of the main species as a function of time $(\mathrm{UTC}+2)$.

\section{Results}

\subsection{Mass concentrations}

Mass concentrations of ammonium $\left(\mathrm{NH}_{4}^{+}\right)$, nitrate $\left(\mathrm{NO}_{3}^{-}\right)$, sulphate $\left(\mathrm{SO}_{4}^{2-}\right)$ and total organics $(\mathrm{Org})$ in submicron particles were calculated according to the standard AMS data analysis procedure (Jimenez et al., 2003; Allan et al., 2004; Alfarra et al., 2004). Average mass concentrations (mass fractions in parenthesis) were $0.20 \mu \mathrm{g} / \mathrm{m}^{3}(10 \%), 0.25 \mu \mathrm{g} / \mathrm{m}^{3}$ (12\%), $0.33 \mu \mathrm{g} / \mathrm{m}^{3}(16 \%)$ and $1.24 \mu \mathrm{g} / \mathrm{m}^{3}(61 \%)$ for ammonium, nitrate, sulphate and organics, respectively. Other species such as non-sea salt chloride and polycyclic aromatic hydrocarbons (PAH) were ignored, because their average concentrations were only a few nanograms per cubic meter, i.e. less than their detection limits (Drewnick et al., 2009).

Concentrations of the main species are shown in Fig. 1. All times reported here are in Finnish winter time (UTC+2). It is possible that the organic peak on 3 April is from Tampere or Korkeakoski, which is a nearby village with a sawmill.

The time-dependent organic mass spectrum was analyzed by the PMF method as described in Sect. 2.4.1. As in previous studies (Zhang et al., 2007), two types of oxygenated organic aerosol (OOA) groups were found. Other commonly found organic groups such as hydrocarbon-like and wood burning organic aerosol (Lanz et al., 2007) were not seen here. This is not surprising since their characteristic peaks were practically absent from the observed mass spectra, namely, $\mathrm{m} / \mathrm{z}, 57$ and $\mathrm{m} / \mathrm{z}, 60$ peaks were only $1.1 \%$ and $0.2 \%$ of the total signal, respectively.

Mass spectra of the two organic groups are shown in Fig. 2. The upper spectrum is typical for type 1 oxygenated organic aerosol (OOA1) and the lower spectrum is closest to type 2 OOA (OOA2) shown in Lanz et al. (2007). Published OOA1 spectra are commonly very similar, but OOA2 spectra can have some differences (see e.g. Lanz et al., 2007; Ulbrich et al., 2009; Ng et al., 2009). This variability may be

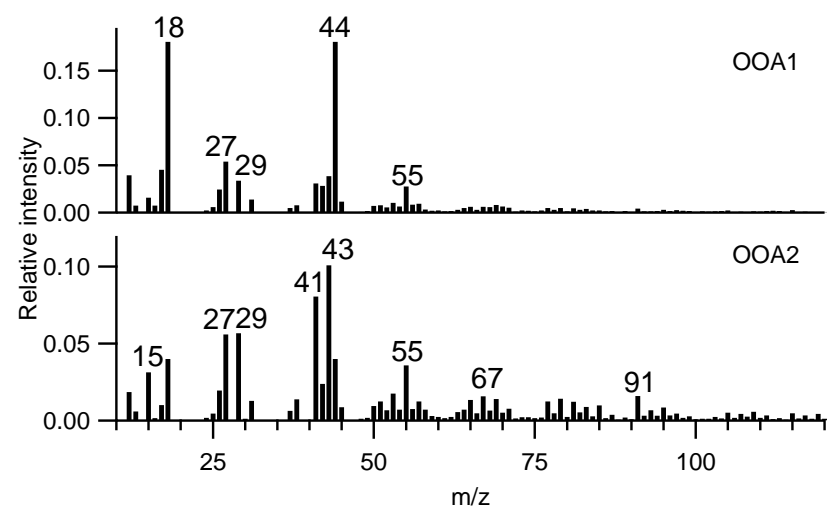

Fig. 2. Mass spectra of the two organic aerosol groups.

due to small differences between instruments and in instrument adjustments, but it is also possible that OOA2 species and their age depend on location. For example, it could be expected that Hyytiälä OOA2 species are slightly different than those in an urban background site in Switzerland (Lanz et al., 2007).

OOA1 is a low-volatility, highly oxidized, aged, longrange transported background organic aerosol fraction (Lanz et al., 2007; Huffman et al., 2009). Due to its high oxidation ratio, OOA 1 species are likely to be somewhat hygroscopic. The less oxidized OOA2 is composed of possibly semi-volatile photo-oxidation products of volatile organic vapours (Lanz et al., 2007). As a result, the OOA2 concentration has a diurnal cycle with maximum during night, especially after days with elevated photochemistry (Lanz et al., 2007). This is in good agreement with the findings of Ulbrich et al. (2009).

Oxygen content of the organic groups can be estimated from their $\mathrm{m} / \mathrm{z} 44$ peaks (Aiken et al., 2008). As described in Sect. 2.4.1, the $\mathrm{m} / \mathrm{z} 44$ peaks of the OOA groups depend on the rotational parameter FPEAK, and a mean FPEAK value was selected from all reasonable FPEAKs. The range of possible $m / z, 44$ values is then from $17-21$ and $2-5 \%$ for OOA 1 and OOA2, respectively. Based on the Aiken et al. (2008) linear fit between oxygen to carbon atomic ratio $(\mathrm{O}: \mathrm{C})$ and $\mathrm{m} / \mathrm{z}, 44$ peak, our OOA 1 and OOA2 O:C values are about $0.77 \pm 0.10$ and $0.23 \pm 0.08$, respectively. Explicit $\mathrm{O}: \mathrm{C}$ values can not be calculated from the unit $\mathrm{m} / \mathrm{z}$ resolution data. As shown in Jimenez et al. (2009) and Ng et al. (2009), these $\mathrm{m} / \mathrm{z}, 44$ and $\mathrm{O}: \mathrm{C}$ values are very representative of the range of OOA2 (SV-OOA) and OOA1 (LV-OOA) observed in many AMS measurements.

Concentrations of the two OOA groups are shown in Fig. 3. Average mass concentrations (mass fractions from the total mass) of OOA1 and OOA2 are $0.61 \mu \mathrm{g} / \mathrm{m}^{3}(30 \%)$ and $0.64 \mu \mathrm{g} / \mathrm{m}^{3}$ (32\%), respectively.

Table 1 contains correlation coefficients and their squares $\left(r\right.$ and $r^{2}$ ) for OOA1, OOA2, $\mathrm{NH}_{4}^{+}, \mathrm{NO}_{3}^{-}$and $\mathrm{SO}_{4}^{2-}$ mass 


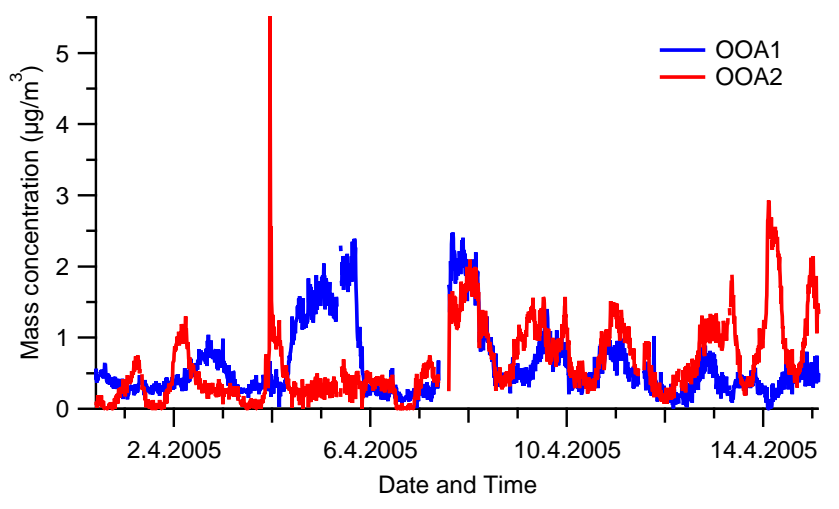

Fig. 3. Mass concentrations of the two organic aerosol groups.

concentrations. As expected, ammonium is correlated with sulphate and nitrate, which means that ammonium sulphate and ammonium nitrate are the main inorganic salts. Ammonium, nitrate and sulphate are also correlated with OOA1, because they all are mostly long-range transported. OOA2, which is likely from local sources, is least correlated with the other species. However, in good agreement with the findings of Lanz et al. (2007), $\mathrm{NO}_{3}^{-}$and OOA2 were clearly correlated during the clean air periods. For example, their correlation coefficient for the period from 31 March 2005 10:00 UTC+2 to 3 April $200522: 30 \mathrm{UTC}+2$ is $0.83\left(r^{2}=0.68\right)$.

\subsection{Correlation with growth factors}

When (time-dependent) volume fractions of particulate species and their constant pure component growth factors are known, it is possible to predict (time-dependent) mixed particle growth factors by using the ZSR mixing rule (Eq. 2). Volume fractions can be obtained from VTDMA measurements or these can be calculated from mass concentrations of the AMS species when their densities are known. Our purpose is to find optimal pure component growth factor values for the OOA groups. Pure component growth factors are determined by fitting the ZSR equation (Eq. 2) containing known volume fractions from both AMS (Sect. 3.2.1) and VTDMA (Sect. 3.2.2) measurements to the measured HGF and EGF values. As a result, there will be four sets of pure component growth factors, i.e. ethanol and water growth factors for both AMS and VTDMA groups. By using the fitted pure component growth factors and measured volume fractions, the ZSR equation can be used in predicting growth factors (Sect. 3.2.3).

\subsubsection{Growth factor correlations based on AMS data}

There are multiple ways to calculate volume fractions for the ZSR equation. For example, it is possible to estimate concentrations of known inorganic compounds, e.g. $\left(\mathrm{NH}_{4}\right)_{2} \mathrm{SO}_{4}$ and $\mathrm{NH}_{4} \mathrm{NO}_{3}$, from ion concentrations. It is also possible to use separate species or sums of organic groups,
Table 1. Pearson correlation coefficients $(r)$ and their squares for the mass concentrations of the main species.

\begin{tabular}{lccc}
\hline & & $r$ & $r^{2}$ \\
\hline OOA2 & OOA1 & 0.16 & 0.03 \\
OOA2 & $\mathrm{NO}_{3}^{-}$ & 0.37 & 0.14 \\
OOA2 & $\mathrm{NH}_{4}^{+}$ & 0.42 & 0.18 \\
OOA2 & $\mathrm{SO}_{4}^{2-}$ & 0.50 & 0.25 \\
OOA1 & $\mathrm{SO}_{4}^{2-}$ & 0.62 & 0.38 \\
$\mathrm{NO}_{3}^{-}$ & $\mathrm{SO}_{4}^{2-}$ & 0.68 & 0.46 \\
OOA1 & $\mathrm{NO}_{3}^{-}$ & 0.75 & 0.57 \\
OOA1 & $\mathrm{NH}_{4}^{+}$ & 0.79 & 0.63 \\
$\mathrm{NH}_{4}^{+}$ & $\mathrm{SO}_{4}^{2-}$ & 0.84 & 0.71 \\
$\mathrm{NH}_{4}^{+}$ & $\mathrm{NO}_{3}^{-}$ & 0.88 & 0.78 \\
\hline
\end{tabular}

ions or salts. Densities are needed for calculating volume concentrations from mass concentrations; these are available for the inorganic compounds, but not for the organic groups. Different volume fraction approaches were tested by fitting the ZSR model (Eq. 2) to the experimental HGF and EGF values (measured for dried $50 \mathrm{~nm}$ particles at about $88 \%$ and $82 \%$ saturation ratios, respectively). Fitting parameters, i.e. pure component growth factors in water and ethanol vapours, were forced to be greater or equal to one as this is commonly the physical minimum growth factor value. Calculated volume fractions were noisy when the total mass concentration is below $0.5 \mu \mathrm{g} / \mathrm{m}^{3}$, so these points were not included in the fittings. More details about the growth factor correlation are given in the supplementary material (http://www.atmos-chem-phys.net/ 10/2063/2010/acp-10-2063-2010-supplement.pdf).

It was found that HGF predictions were significantly better when OOA1 and OOA2 were used instead of total organic mass, but predictions were not sensitive to speciation of the inorganic species. Therefore, a simple ZSR model containing OOA1, OOA2 and inorganic ions as a sum $\left(\mathrm{NH}_{4}^{+}+\mathrm{NO}_{3}^{-}+\mathrm{SO}_{4}^{2-}\right)$, was selected. Because these are not chemical substances, their densities can not be found from the literature. Densities of the sulphate and nitrate salts are between 1.7 and $1.8 \mathrm{~g} / \mathrm{cm}^{3}$, so the inorganic density was set to $1.7 \mathrm{~g} / \mathrm{cm}^{3}$. For example, Kiendler-Scharr et al. (2009) report an average organic density of $1.3 \mathrm{~g} / \mathrm{cm}^{3}$. Because OOA 1 is expected to be more dense than OOA2, their densities were set to $1.4 \mathrm{~g} / \mathrm{cm}^{3}$ and $1.2 \mathrm{~g} / \mathrm{cm}^{3}$, respectively. Fitted pure component EGF and HGF values as well as average volume fractions of the species are given in the Table 2. The correlation coefficient $(r)$ was 0.63 for both HGF and EGF fits.

When testing different fitting methods (linear and ZSR models, weighted and unweighted minimization, total mass concentration noise limits, speciation and densities of the species), it was found that growth factors of OOA2 and 
Table 2. Fitted pure component hygroscopic (HGF) and ethanol (EGF) growth factors and their standard deviations as well as average volume fractions $(\xi)$ for the inorganic species and the two organic groups.

\begin{tabular}{lrrr}
\hline & HGF & EGF & $\xi(\%)$ \\
\hline $\mathrm{NH}_{4}^{+}+\mathrm{NO}_{3}^{-}+\mathrm{SO}_{4}^{2-}$ & $1.53 \pm 0.02$ & $1.00 \pm 0.01$ & 28 \\
$\mathrm{OOA} 1$ & $1.29 \pm 0.02$ & $1.12 \pm 0.01$ & 35 \\
$\mathrm{OOA} 2$ & $1.00 \pm 0.02$ & $1.16 \pm 0.01$ & 37 \\
\hline
\end{tabular}

inorganic species were always very similar, but OOA1 HGF values showed some variability. It appears that most OOA2 species are non-hygroscopic, but a range of water soluble species with different hygroscopic properties are included in OOA1.

Fitted growth factors given in Table 2 are in good agreement with known and expected chemical and physical properties of the species. Ammonium, nitrate and sulphate salts are highly hygroscopic, but sparingly soluble to ethanol. For example, ethanol GF of a $100 \mathrm{~nm}$ ammonium sulphate particle is 1.0 and hygroscopic GF is 1.46 at $80 \%$ saturation ratio, and at $90 \%$ saturation ratio they are 1.0 and 1.76 , respectively (Joutsensaari et al., 2001). It is not surprising that OOA1 HGF is higher than that of OOA2, because OOA1 is more oxidized and polar. Water soluble organics have a wide range of hygroscopic growth factors. For example, low molecular weight dicarboxylic acids, which are counted as OOA1, have HGF between 1.0 and 1.37 at $80 \%$ RH (Prenni et al., 2001). In addition to the known organic species, hygroscopic growth factors have been measured for condensed oxidation products of organic vapours (e.g., Varutbangkul et al., 2006). Measured growth factors depend on the precursor gases, seed aerosol and oxidizing agents, but generally are from 1.0 to 1.2 at $85 \%$ RH for various particle sizes.

\subsubsection{Growth factor correlations based on VTDMA data}

Similar to the AMS data case, the ZSR equation (Eq. 2) with volume fractions from VTDMA measurements was fitted to the measured water and ethanol growth factors. Average volume fractions and fitted pure component growth factors, which represent average growth properties of particulate species evaporating at the different temperature ranges, are given in Table 3. The correlation coefficient $(r)$ was 0.82 for both HGF and EGF fits. Note that temperature ranges start from $50^{\circ} \mathrm{C}$, since observed evaporation was negligible below that temperature.

Sensitivities of the fitted growth factors were tested by doing fits with combined volume fractions. The 50-150 and 150-280 ${ }^{\circ} \mathrm{C}$ temperature ranges are distinct, but the $>280$ and $150-280^{\circ} \mathrm{C}$ volume fractions could be combined. Their combined HGF value (1.47) is roughly the same as that for
Table 3. Fitted hygroscopic (HGF) and ethanol (EGF) growth factors and their standard deviations as well as average volume fractions $(\xi)$ for species evaporating at different temperature ranges.

\begin{tabular}{lrrr}
\hline & HGF & EGF & $\xi(\%)$ \\
\hline $50-150^{\circ} \mathrm{C}$ & $1.00 \pm 0.04$ & $1.19 \pm 0.01$ & 51 \\
$150-280^{\circ} \mathrm{C}$ & $1.52 \pm 0.04$ & $1.00 \pm 0.02$ & 38 \\
$>280^{\circ} \mathrm{C}$ & $1.28 \pm 0.12$ & $1.00 \pm 0.04$ & 11 \\
\hline
\end{tabular}

$150-280^{\circ} \mathrm{C}$, indicating the $>280^{\circ} \mathrm{C}$ growth factors are not reliable. It is possible that this volume fraction just contains species like crustal material, sea salt and black carbon which have very different growth factors. Charring of the organics is not likely source of non-volatile material (Philippin et al., 2004), but polymerized organics can have very high volatilization temperatures (Kalberer et al., 2004; Ehn et al., 2007b). Also, the low average volume fraction (11\%) and similarity with the $150-280^{\circ} \mathrm{C}$ fraction makes the fit less sensitive to $>280^{\circ} \mathrm{C}$ growth factor values.

The interpretation of the fitted growth factors (Table 3 ) is not as simple as in the case of the AMS fitting (Table 2). Mixtures of crustal material, sea salt and black carbon, which are not volatile at $280^{\circ} \mathrm{C}$, can explain $>280^{\circ} \mathrm{C}$ growth factor values. Volatilization temperatures of ammonium sulphate and ammonium bisulphate are around $200^{\circ} \mathrm{C}$ (Johnson et al., 2004; Villani et al., 2007), which is in good agreement with the fitted $150-280^{\circ} \mathrm{C}$ growth factors. Ammonium nitrate should have been evaporated below $150^{\circ} \mathrm{C}$ (Johnson et al., 2004; Villani et al., 2007), but this is not seen in the fitted $50-150{ }^{\circ} \mathrm{C}$ growth factors or even in correlation between nitrate and $50-150^{\circ} \mathrm{C}$ volume fractions (not shown here). It is possible that nitrate comes from less volatile organic compounds, or that there is less nitrate in $50 \mathrm{~nm}$ particles than in $\mathrm{PM}_{1}$ mass. Fitted $50-150{ }^{\circ} \mathrm{C}$ growth factors are similar to those of the OOA2 (Table 2), which is in agreement with the previous studies showing that OOA2 evaporates mainly before $150^{\circ} \mathrm{C}$ (Huffman et al., 2009). In addition to OOA2, about half of the OOA1 evaporate at $50-150^{\circ} \mathrm{C}$ (Huffman et al., 2009), but this is not seen in the fitted growth factors. It seems that OOA1 species have a wide range of evaporation temperatures so that more volatile OOA1 species have lower HGF and higher EGF values than less volatile OOA1 species. Evaporation of the species can be estimated by correlating AMS and VTDMA volume fractions. This is done in Sect. 3.3.

\subsubsection{Growth factor predictions}

Experimental and predicted (Eq. 2 with the measured volume fractions and the fitted pure component growth factors) hygroscopic (HGF) and ethanol (EGF) growth factors, volume fractions used in the predictions and particle number size distribution are shown in Fig. 4. Because AMS and VTDMA 


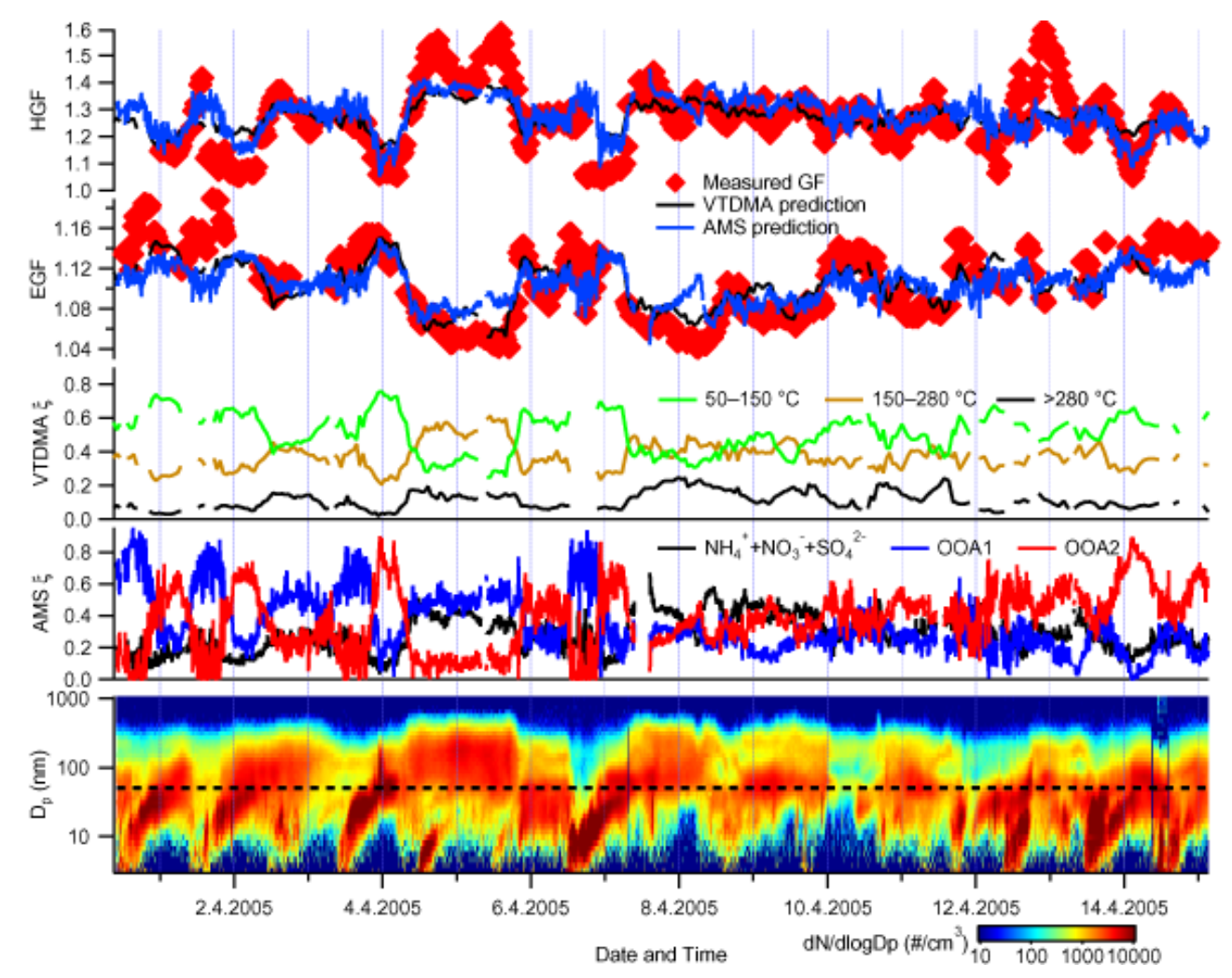

Fig. 4. Measured and predicted (Eq. 2 with parameters from Tables 2 and 3 and volume fractions from this figure) growth factors, volume fractions from VTDMA and AMS measurements and aerosol number size distribution $\left(\mathrm{d} N / \mathrm{d} \log D_{p}\right)$ measured by DMPS. The dashed line in the size distribution represents $50 \mathrm{~nm}$ particle size.

predictions are very similar, it seems that the average composition of submicron particles measured by the AMS is similar to that of $50 \mathrm{~nm}$ particles. There is only one clear difference in the early morning of 8 April.

Taking into account the simplicity of the model (only three groups of species with constant properties) and complexity of real aerosol composition, the predictions are good. First of all, the trends of the growth factors, especially for EGF, are well predicted in this two week long time period. For example, EGF seems to have a minimum in the middle of the campaign and this trend is also seen in the prediction. Secondly, the magnitudes of the measured growth factors are in good agreement with the calculated volume fractions. For example, the smallest hygroscopic growth factors are seen when the least hygroscopic OOA2 dominates particle mass.

As can be seen from Fig. 4, there are some time periods when the correlation is not that good (e.g. 12-13 April). It is not surprising that aerosol growth properties could not be predicted perfectly from average properties of only three groups. Detailed properties of the inorganic species depend on sulphate to nitrate ratio and acidity. Similarly, at least OOA1 species seem to have a wide range of different hygroscopic growth factors. Variability in the volume fraction and GF measurements increase also model deviations. Especially
AMS volume fractions, which are based on non-refractory $\mathrm{PM}_{1}$ mass, are noisy when total concentration is low. Finally, volume fractions are based on particle volume, while growth factors come from number size distributions, where smaller particles have a greater effect.

A double HGF peak higher than the predictions is seen on 4-5 April that coincides with increased $150-280^{\circ} \mathrm{C}$ fractions while both measured and predicted EGF's are very low. A high sulphate to nitrate ratio might contribute to the high HGF peaks. However, as organics are about half of the total volume, the inorganic fraction should be even more hygroscopic than pure sulphuric acid so that the absolute values of the peaks (ca. 1.6) could be fully explained.

Largest deviations in modelled HGF are seen during 1213 April. Two peaks in the measured HGF do not correspond to any change in the AMS composition or VTDMA volume fraction. It appears these measured HGF values are not real, but most likely caused by temperature and RH fluctuations in the instrument. These points were not ignored, but they have only a minor effect on the fitted HGF values.

The GF models appear to overestimate the lowest hygroscopic growth factors, which are commonly occurred in the evenings of nucleation event days. Low HGF are expected, because fresh $50 \mathrm{~nm}$ particles can have very high organic 


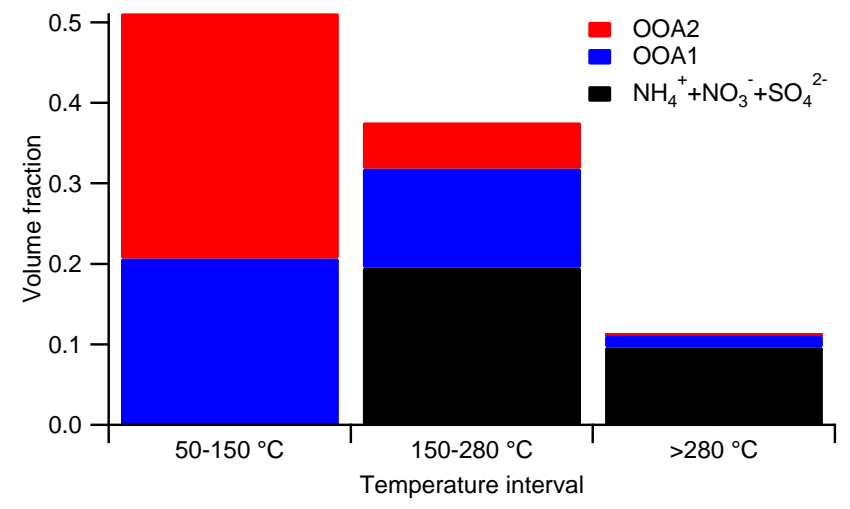

Fig. 5. Average volume fractions and compositions of matter evaporating at three different temperature intervals (see Sect. 3.3).

Table 4. Evaporation probabilities and their standard deviations (\%) as a function of temperature for the AMS compound groups.

\begin{tabular}{lrrr}
\hline & OOA2 & OOA1 & $\mathrm{NH}_{4}^{+}+\mathrm{NO}_{3}^{-}+\mathrm{SO}_{4}^{2-}$ \\
\hline $50-150^{\circ} \mathrm{C}$ & $83 \pm 2$ & $59 \pm 2$ & $0 \pm 3$ \\
$150-280^{\circ} \mathrm{C}$ & $16 \pm 1$ & $35 \pm 1$ & $69 \pm 2$ \\
$>280^{\circ} \mathrm{C}$ & $1 \pm 1$ & $4 \pm 1$ & $34 \pm 1$ \\
\hline
\end{tabular}

volume fractions (Allan et al., 2006). It is also possible that organic species are somewhat different during nucleation events. Predictions would be better for these low HGF time periods, if the less volatile OOA1 fraction were less hygroscopic.

\subsection{Volatilities of the species}

Volatilities of the AMS species were estimated by correlating VTDMA and AMS volume fractions. Our simple linear model, $\xi_{\Delta T}^{\mathrm{VTDMA}}=\sum_{i} p_{i, \Delta T} \xi_{i}^{\mathrm{AMS}}$, is based on assumption that each VTDMA volume fraction $\left(\xi_{\Delta T}^{\mathrm{VTDMA}}\right)$ can be described as a sum of AMS volume fractions $\left(\xi_{i}^{\mathrm{AMS}}\right)$ multiplied by their average evaporation probabilities $\left(p_{i, \Delta T}\right)$. Different AMS species and groups were tested, and again it seems that OOA1, OOA2 and the sum of inorganic ions are the groups needed. Three separate linear fits, one for each VTDMA volume fraction, were made while forcing the fitting coefficients $\left(p_{i, \Delta T}\right)$ to be positive. Correlation coefficients $(r)$ of the 50 $150,150-280$ and $>280^{\circ} \mathrm{C}$ fits are $0.82,0.77$ and 0.70 , respectively. Fitted parameters are given in Table 4 .

Average compositions of the three VTDMA volume fractions can be calculated by multiplying average AMS volume fractions by the fitted probabilities. These are shown in Fig. 5. For example, the first bar shows that about half of the particle volume is evaporated at $50-150{ }^{\circ} \mathrm{C}$, and this evaporating matter is OOA2 (60\%) and OOA1 (40\%).

Just as in the case of VTDMA growth factor fits, the results are not reliable for the highest temperature range. Evapora-

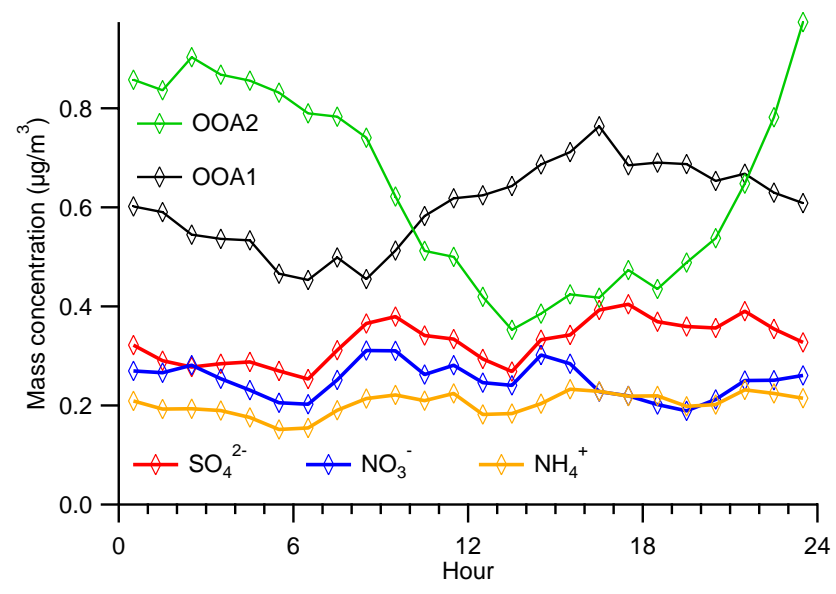

Fig. 6. Diurnal cycles for OOA1, OOA 2 and the inorganic species. Averages are based on 15 measurement days.

tion probabilities and average volume fractions of the 150 280 and $>280^{\circ} \mathrm{C}$ temperatures could be combined.

The results show that OOA 2 is the most volatile organic group, evaporating almost completely between $50-150^{\circ} \mathrm{C}$. OOA1 species have a wide range of volatilization temperatures. About $60 \%$ of OOA 1 evaporates at $50-150{ }^{\circ} \mathrm{C}$, in good agreement with the Huffman et al. (2009) results. Inorganic species evaporate above $150^{\circ} \mathrm{C}$, consistent with the previous studies (Johnson et al., 2004; Villani et al., 2007).

Estimated average compositions of the VTDMA volume fractions (Table 4) and fitted growth factors (Table 3) are in relatively good agreement. OOA1 species have a wide range of volatilization temperatures and hygroscopic growth factors. The more volatile OOA1 fraction evaporates at 50 $150^{\circ} \mathrm{C}$ and it can be even hydrophobic, thus it is in that sense similar to OOA2. The less volatile OOA1 fraction evaporates at $150-280^{\circ} \mathrm{C}$ and it can have as high growth factors as the common inorganic species do.

\subsection{Diurnal variations}

Diurnal cycles of OOA1, OOA2 and the inorganic species represented by mass concentration mean values are shown in Fig. 6. More detailed diurnal concentration cycles including 25\%,50\% and $75 \%$ quartiles are shown in the supplementary material (http://www.atmos-chem-phys.net/ 10/2063/2010/acp-10-2063-2010-supplement.pdf). Ammonium and sulphate do not have clear diurnal cycles. Nitrate concentrations depend mainly on the pollution level, but there is also a weak diurnal cycle similar to that of OOA2 during clean periods. The nitrate cycle can be seen when nitrate mass concentration is divided by daily average mass concentrations (not shown here). OOA1 has a weak diurnal cycle with maximum in the afternoon and minimum in the morning. Unlike the other species, OOA2 has a clear diurnal cycle similar to that found by Lanz et al. (2007). There is 
a minimum in OOA2 mass concentration in early afternoon and maximum during night. Multiple factors related to dynamics between meteorological conditions and OOA sources and sinks likely contribute to the observed OOA2 diurnal cycle. Specific possible factors include variations in mixing layer height and temperature; and also night time ozonolysis reactions. It can be expected that OOA2 is composed of oxidation products of locally emitted volatile organic compounds (VOCs); unlike the aged and well mixed OOA1 and inorganic species, they have maximum concentrations close to the source. Consequently, dilution due to increasing mixing layer height is a possible explanation for the observed concentration decrease in the morning - and the daytime plateau (slow concentration changes due to high mixing volume). For the concentration increase in the evening, a combination of reduced mixing layer height and continued OOA2 production, can explain increasing OOA2 concentration. This is possible, because diurnal variation in ozone concentration is not that large. When OOA2 concentration increases in the evening (from 18:00 UTC+2 to 24:00 UTC+2) average ozone concentration decreases from about 46 ppt to 41 ppt. OOA 2 condensation may also be enhanced by decreasing temperature after sunset, since OOA2 is semi-volatile as described below. It can be expected that much of the OOA2 is produced during the daytime due to higher VOC emissions and photochemistry (Tarvainen et al., 2005). According to Lanz et al. (2007), gaseous OOA2 is not condensed until the temperature decreases in the evening. Thus, evaporation of OOA 2 could also contribute to the concentration decrease in the morning. This explanation is in good agreement with their finding that OOA2 concentration is higher after the days with higher photochemical activity (Lanz et al., 2007). On the other hand, correlation between OOA2 concentration and photochemical activity is not clear for the current Hyytiälä data and our volatility measurements indicate that OOA2 is not that volatile, suggesting night time ozonolysis may also contribute.

\subsection{Correlation with back trajectories}

The HYSPLIT (HYbrid Single-Particle Lagrangian Integrated Trajectory) model (Draxler and Rolph, 2003) was used to calculate back trajectories (here just termed trajectories) for every hour, giving 355 trajectories in 15 days. Trajectory end point (Hyytiälä) altitudes were set to $500 \mathrm{~m}$ above ground level and vertical motion was modelled. Each trajectory is $96 \mathrm{~h}$ long containing one coordinate point for every hour.

It is possible to estimate sources of the particulate species, especially long-range transport, by comparing measured concentrations with the origin of air masses. Because local wind directions can be misleading, air mass origin was calculated from the trajectories. Air mass origin, expressed as a compass heading from Hyytiälä, is an average of trajectory point headings weighted by their distances from Hyytiälä. Weights were used to decrease the effect of trajectory points close to Hyytiälä, but the weights had only a small effect on results.

One simple way to estimate anthropogenic influence on aerosol mass concentrations is to calculate average population densities (number of people per $\mathrm{km}^{2}$ ) for each trajectory. A population density map for year 2000 was downloaded from SEDAC web pages. ${ }^{1}$ Because of the high resolution of the population density map ( $2.5 \mathrm{arc}$ min, which is about $5 \mathrm{~km}$ in distance) and the fact that population densities can change a lot in relatively short distances, trajectory coordinate points were interpolated for every three minutes from the original one-hour time resolution.

In addition to the average population density, aerosol concentration could depend on the time that air masses spend over land. With the exception of sea salt, most aerosol sources are on land areas. The majority of the population density map values marked with "no data" flag indicate sea or lake. Some areas such as glaciers are also marked with that flag, but their areal fraction is minimal and it can be expected that these areas have only a small contribution to the particle mass. Therefore, all map points where data was available were counted as land.

Average air mass origin, average population density and time spend over land in addition to the AMS mass concentrations $\left(\mu \mathrm{g} / \mathrm{m}^{3}\right)$ and total particle volume concentration $\left(\mu \mathrm{cm}^{3} / \mathrm{m}^{3}\right)$ from DMPS measurements are shown in Fig. 7. When a trajectory crosses some of the most densely populated areas, there will be a peak in the average population density. For example, the highest peak seen on 2 April is from a trajectory crossing metropolitan London having population densities up to $10000 \# / \mathrm{km}^{2}$. It is not surprising that such a sharp peak is not observed in the aerosol mass concentrations, because trajectories are not that accurate and mixing decreases possible peak concentrations.

From Fig. 7, air mass origin can be divided into clean and polluted sectors by putting the limit on air masses arriving from a few degrees South from West. As an example, three clear pollution time periods are separated by vertical lines. When air masses are coming from the clean sector (from West to North), volume concentrations and average population densities have the lowest values. These particles, which can be considered as natural background, are composed of nearly equal amounts of OOA1, OOA2 and inorganic species. When air masses are coming from the polluted sector (from South to West), particle volume concentrations and average population densities have the highest values. Pollution particles are dominated by the inorganic

\footnotetext{
${ }^{1}$ Center for International Earth Science Information Network (CIESIN), Columbia University; and Centro Internacional de Agricultura Tropical (CIAT). 2005. Gridded Population of the World Version 3 (GPWv3): Population Density Grids. Palisades, NY: Socioeconomic Data and Applications Center (SEDAC), Columbia University. Available at http://sedac.ciesin.columbia.edu/gpw (map downloaded 7 March 2008).
} 


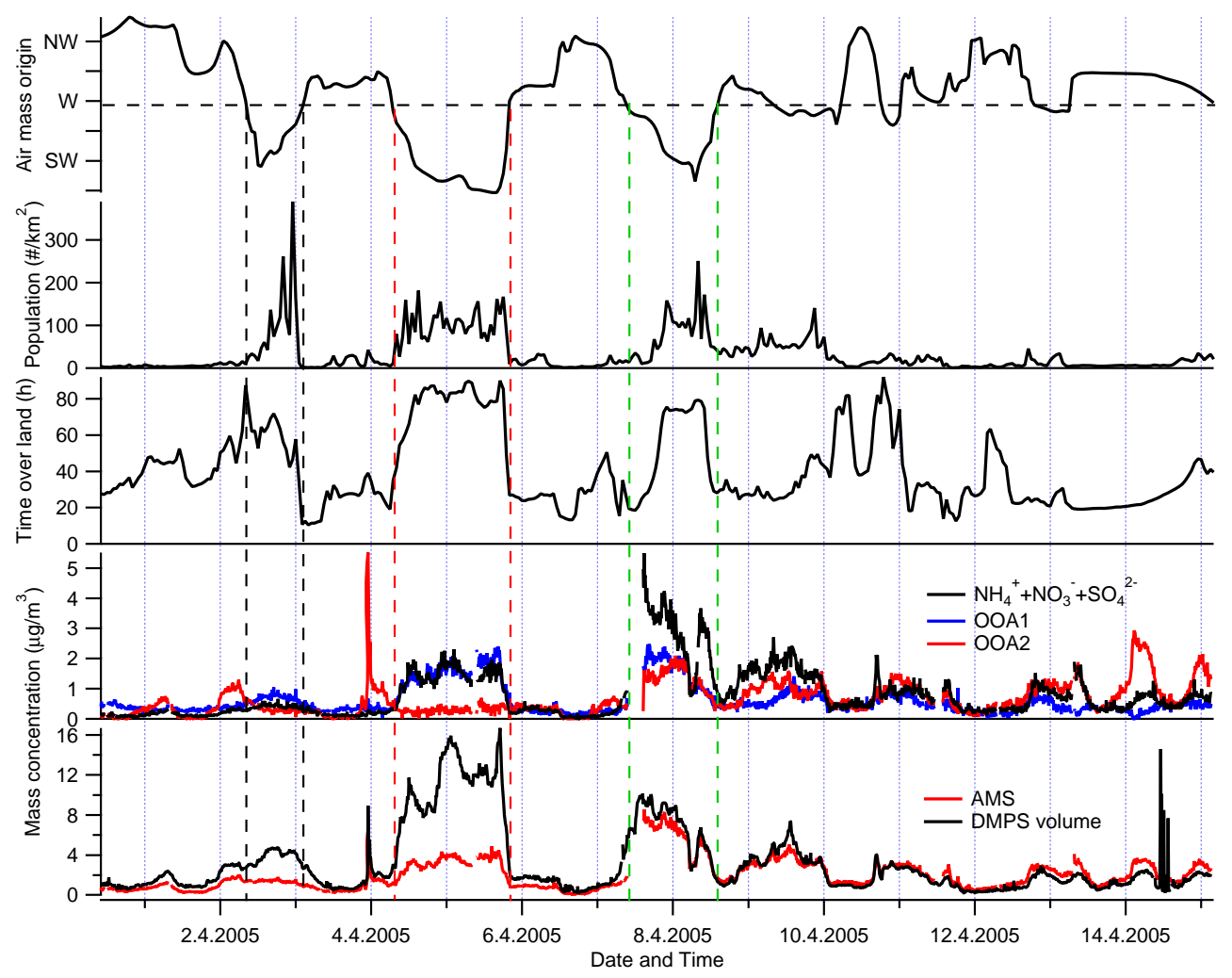

Fig. 7. Average air mass origin, population density, time over land, mass concentrations of the AMS compound groups, total mass concentration $\left(\mu \mathrm{g} / \mathrm{m}^{3}\right)$ from AMS measurements and total particle volume $\left(\mu \mathrm{cm}^{3} / \mathrm{m}^{3}\right)$ from DMPS measurements.

species and OOA1. The OOA2 mass concentration is about the same as in the clean air. Therefore, these pollution particles are less volatile, hygroscopic growth factors have the highest values and ethanol growth factors have the lowest values.

Figure 8 shows total particle volume and concentrations of the organic and inorganic groups as a function of average population density. The black lines are linear fits to the values, and also the fitting coefficients are given. Origin of the air masses is represented by the marker colour. As can be seen from Fig. 7, ratio of the AMS mass and DMPS volume change due to the non-standard AMS adjustments. Therefore, AMS concentration values measured before 7 April 2005 12:00 UTC+2 were multiplied by a factors of two. When air masses are coming from the clean sector (from West to North), total particle volume is about constant, usually below $4 \mu \mathrm{cm}^{3} / \mathrm{m}^{3}$, and the average population density is mostly below $40 \# / \mathrm{km}^{2}$. Total particle volume is higher when air masses come from the polluted sector, and the higher the average population density, the higher the total particle volume. Inorganic species and OOA 1 follow this trend, but OOA 2 concentration is independent of the average population density or long-range transported anthropogenic emissions. Coefficients of the linear fits can be interpreted so that the offsets represent average background concentrations and slopes represent the effect of anthropogenic contribution. Qualitatively, this means that an average background particle is composed of nearly equal amounts of OOA 1, OOA 2 and inorganic species, and long-range transported matter is composed of OOA1 and inorganic species. Quantitative interpretation or generalization is not recommended due to simplicity of the method and shortness of the time series.

Tunved et al. (2006) found that, due to precursor gas emissions from the boreal forests, clean sector aerosol volume concentration depend on the time spend over land, but this is not seen in the current data. Correlation coefficients confirmed that clean sector particle volume and mass concentrations are practically independent of air mass origin, population density and time spend over land. It is possible that current data set is too short for seeing the correlation; i.e. 224 clean sector trajectories mainly from April, compared to 4400 trajectories from April to September in Tunved et al. (2006).

In addition to the clean sector case, it seems that the OOA2 concentration is independent of air mass history also in polluted air masses. Again, it is possible that the correlation is not seen due to the shortness of the current data series. On the other hand, the observed OOA2 diurnal cycle indicates short OOA2 life time and local sources, which means that OOA2 concentrations really are independent of air mass history. 


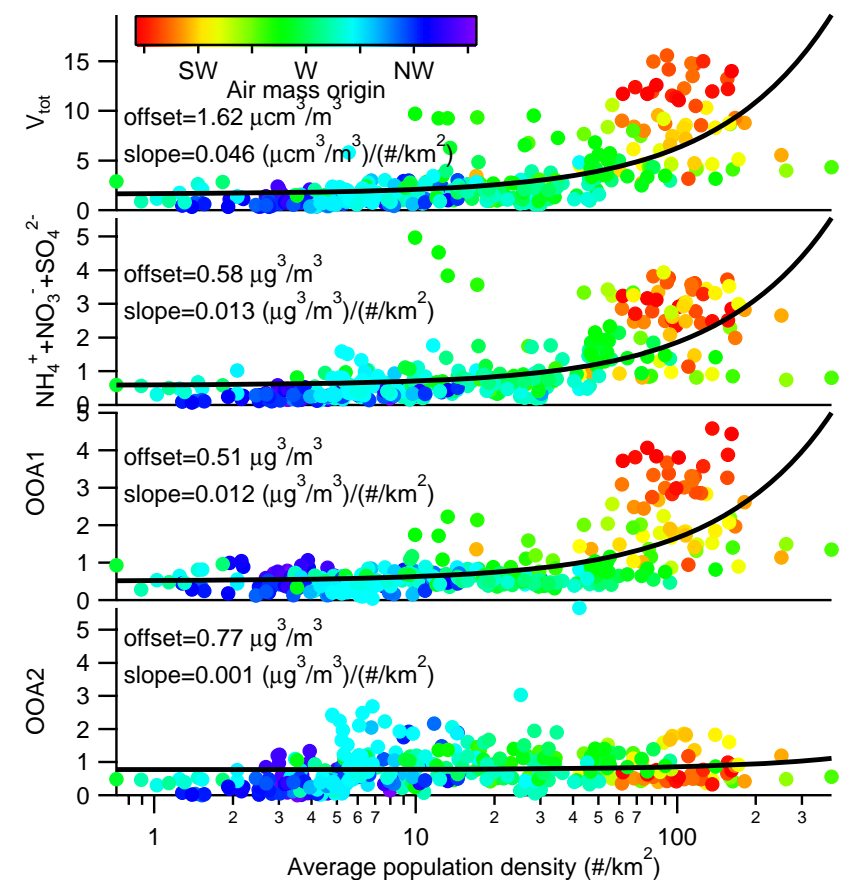

Fig. 8. Total particle volume $\left(\mu \mathrm{cm}^{3} / \mathrm{m}^{3}\right)$ from DMPS and mass concentrations $\left(\mu \mathrm{g} / \mathrm{m}^{3}\right)$ from AMS measurements as a function of average population density. Marker colour represents air mass origin. Mass concentrations from the AMS measurements have been corrected to match with the total particle volume measured by the DMPS. Parameters of the linear fits (black lines) are given in the figures.

\section{Conclusions}

A quadrupole AMS was used to measure the composition of submicron aerosol in Hyytiälä, which is a rural forested measurement site in southern Finland. During the 15 day campaign from 31 March to 15 April 2005, the average particle mass concentration was quite low $\left(2.0 \mu \mathrm{g} / \mathrm{m}^{3}\right)$ and dominated by organics ( $61 \%$ of the mass). In addition to the standard AMS data analysis, two types of oxygenated organic aerosol groups, more oxidized OOA1 (or LV-OOA) and less oxidized OOA2 (or SV-OOA), were identified from the total organic mass spectrum by applying a positive matrix factorization (PMF) method.

OOA 1 and OOA2 properties were estimated by correlating their concentrations with data from three ultrafine tandem differential mobility analyzers measuring particle volatility (VTDMA) and hygroscopic (HTDMA) and ethanol (OTDMA) growth factors. In practice, volume fractions were calculated for AMS compound groups (OOA1, OOA2 and sum of inorganic species) and VTDMA groups (species evaporating at $50-150,150-280$ and $>280^{\circ} \mathrm{C}$ ), and the ZSR equation was fitted to the measured hygroscopic and ethanol growth factors. Each of the four fittings produced three pure component growth factors representing average growth properties of the groups. Volatilities of the AMS species were estimated by correlating volume fractions from AMS and VTDMA measurements. Correlations show that the OOA2 species have high ethanol growth factors and low hygroscopic growth factors. Most of the OOA2 species evaporate at $50-150{ }^{\circ} \mathrm{C}$. On the other hand, OOA1 species seem to have a wide range of different volatilization temperatures and hygroscopic growth factors, but on the average OOA1 species are less volatile and more hygroscopic. About $60 \%$ of the OOA 1 volume is evaporated at $50-150{ }^{\circ} \mathrm{C}$ and those species are similar to the OOA 2 species. The remaining OOA 1 species evaporate at $150-280^{\circ} \mathrm{C}$ and some of them can be as hygroscopic as the common inorganic salts.

Fitted pure component growth factors and volatilities can be used in predicting growth factors and particle volatility. When the simplicity of the models and simplifications in particle composition are taken into account, volatility and growth factor predictions are surprisingly good. In general, model fits to the volatility and growth factor data were far superior when using OOA1 and OOA2 factors, in contrast to just using the total organic volume, indicating that the organic group factorization distinguishes clear differences in physical and chemical properties. Moreover, the range and magnitude of the levels of oxidation (e.g. $\mathrm{m} / \mathrm{z} 44$ and O:C values), volatility (via VTDMA) and hygroscopic growth factor span the range of observations both in ambient and laboratory chamber experiments. This work, for the first time, simultaneously couples all three of these observations.

The origin of the OOA1 and OOA2 species was estimated by comparing their concentrations with air mass history based on calculated back trajectories and a population density map. Similarly to the previous studies, it was found that the aged and highly oxidized OOA1 can be related to long-range transported anthropogenic pollutions. The less oxidized and fairly fresh OOA2, or its precursor vapours, can be related to local emissions. Unlike OOA1 and the inorganic species, OOA2 has a clear diurnal cycle with a minimum concentration in daytime. A combination of temperature dependent gas-particle partitioning, changes in the mixing layer height and night time SOA production via ozonolysis likely contribute to this diurnal cycle.

It should be noted that OOA1 has a small diurnal cycle, that is opposite to that of OOA2, increasing after noon and decreasing through the night after sunset. The daytime increase could be due to photochemical production or long range transport into the mixed boundary layer; while the night time decrease could reflect aerosol loss with no production. Just as with OOA2, the diurnal cycle cannot be definitively interpreted.

The results show that by using the PMF method, nonrefractory organic mass can be divided into organic groups which have different chemical and physical properties and sources. These groups can be used in predicting aerosol properties such as hygroscopicity and volatility. Unfortunately, our data set is quite short (only 15 days) so it covers only a limited range of conditions such as ambient 
temperature and air mass origin. For example, it is possible that different organic groups are found in summer or when air masses are coming from the East. The next step is to analyse much longer data series from spring 2007.

Acknowledgements. We thank Maj and Tor Nessling Foundation (grants 2007083 and 2008095), Academy of Finland Center of Excellence program (project number 1118615) and FiDiPro program (D. Worsnop), BACCI (Biosphere-Aerosol-Cloud-Climate Interactions) and QUEST (Quantification of Aerosol Nucleation in the European Boundary Layer) projects for financial support. The authors gratefully acknowledge the NOAA Air Resources Laboratory (ARL) for the provision of the HYSPLIT transport and dispersion model and READY website (http://www.arl.noaa.gov/ready.html) used in this publication. We are also thankful for the personnel of the SMEAR II station, and for T. Anttila, V.-M. Kerminen and M. R. Canagaratna for useful discussions.

Edited by: M. Gysel

\section{References}

Aalto, P., Hämeri, K., Becker, E., Weber, R., Salm, J., Mäkelä, J., Hoell, C., O’Dowd, C., Karlsson, H., Hansson, H.C., Väkevä, M., Koponen, I., Buzorius, G., and Kulmala, M.: Physical characterization of aerosol particles during nucleation events, Tellus B, 53, 344-358, 2001.

Aiken, A. C., DeCarlo, P. F., Kroll, J. H., Worsnop, D. R., Huffman, J. A., Docherty, K. S., Ulbrich, I. M., Mohr, C., Kimmel, J. R., Sueper, D., Sun, Y., Zhang, Q., Trimborn, A., Northway, M., Ziemann, P. J., Canagaratna, M. R., Onasch, T. B., Alfarra, M. R., Prévôt, A. S. H., Dommen, J., Duplissy, J., Metzger, A., Baltensperger, U., and Jimenez, J. L.: O/C and OM/OC ratios of primary, secondary, and ambient organic aerosols with high-resolution time-of-flight aerosol mass spectrometry, Environ. Sci. Technol., 42, 4478-4485, 2008.

Aklilu, Y., Mozurkewich, M., Prenni, A., Kreidenweis, S., Alfarra, M., Allan, J., Anlauf, K., Brook, J., Leaitch, W., Sharma, S., Boudries, H., and Worsnop, D.: Hygroscopicity of particles at two rural, urban influenced sites during Pacific 2001: Comparison with estimates of water uptake from particle composition, Atmos. Environ., 40, 2650-2661, 2006.

Alfarra, M., Coe, H., Allan, J., Bower, K., Boudries, H., Canagaratna, M., Jimenez, J., Jayne, J., Garforth, A., Li, S.-M., and Worsnop, D.: Characterization of urban and rural organic particulate in the Lower Fraser Valley using two Aerodyne aerosol mass spectrometers, Atmos. Environ., 38, 5745-5758, 2004.

Allan, J., Jimenez, J., Williams, P., Alfarra, M., Bower, K., Jayne, J., Coe, H., and Worsnop, D.: Quantitative sampling using an aerodyne aerosol mass spectrometer 1 . Techniques of data interpretation and error analysis, J. Geophys. Res., 108, 4090, doi:10.1029/2002JD002358, 2003.

Allan, J., Delia, A., Coe, H., Bower, K., Alfarra, M., Jimenez, J., Middlebrook, A., Drewnick, F., Onasch, T., Canagaratna, M., Jayne, J., and Worsnop, D.: A generalised method for the extraction of chemically resolved mass spectra from Aerodyne aerosol mass spectrometer data, J. Aerosol Sci., 35, 909-922, 2004.

Allan, J. D., Alfarra, M. R., Bower, K. N., Coe, H., Jayne, J. T., Worsnop, D. R., Aalto, P. P., Kulmala, M., Hyötyläinen, T., Cav- alli, F., and Laaksonen, A.: Size and composition measurements of background aerosol and new particle growth in a Finnish forest during QUEST 2 using an Aerodyne Aerosol Mass Spectrometer, Atmos. Chem. Phys., 6, 315-327, 2006,

http://www.atmos-chem-phys.net/6/315/2006/.

Anttila, P., Hyötyläinen, T., Heikkilä, A., Jussila, M., Finell, J., Kulmala, M., and Riekkola, M.-L.: Determination of organic acids in aerosol particles from a coniferous forest by liquid chromatography mass spectrometry, J. Sep. Sci., 28, 337-346, 2005 a.

Anttila, P., Rissanen, T., Shimmo, M., Kallio, M., Hyötyläinen, T., Kulmala, M., and Riekkola, M.-L.: Organic compounds in atmospheric aerosols from a Finnish coniferous forest, Boreal Environ. Res., 10, 371-384, 2005 b.

Boy, M., Petäjä, T., Dal Maso, M., Rannik, ., Rinne, J., Aalto, P., Laaksonen, A., Vaattovaara, P., Joutsensaari, J., Hoffmann, T., Warnke, J., Apostolaki, M., Stephanou, E. G., Tsapakis, M., Kouvarakis, A., Pio, C., Carvalho, A., Römpp, A., Moortgat, G., Spirig, C., Guenther, A., Greenberg, J., Ciccioli, P., and Kulmala, M.: Overview of the field measurement campaign in Hyytiälä, August 2001 in the framework of the EU project OSOA, Atmos. Chem. Phys., 4, 657-678, 2004,

http://www.atmos-chem-phys.net/4/657/2004/.

Canagaratna, M., Jayne, J., Jimenez, J., Allan, J., Alfarra, M., Zhang, Q., Onasch, T., Drewnick, F., Coe, H., Middlebrook, A., Delia, A., Williams, L., Trimborn, A., Northway, M., DeCarlo, P., Kolb, C., Davidovits, P., and Worsnop, D.: Chemical and microphysical characterization of ambient aerosols with the Aerodyne aerosol mass spectrometer, Mass Spectrom. Rev., 26, 185-222, 2007.

Cavalli, F., Facchini, M. C., Decesari, S., Emblico, L., Mircea, M., Jensen, N. R., and Fuzzi, S.: Size-segregated aerosol chemical composition at a boreal site in southern Finland, during the QUEST project, Atmos. Chem. Phys., 6, 993-1002, 2006, http://www.atmos-chem-phys.net/6/993/2006/.

Draxler, R. and Rolph, G.: HYSPLIT (HYbrid Single-Particle Lagrangian Integrated Trajectory) Model access via NOAA ARL READY Website (http://www.arl.noaa.gov/ready/hysplit4.html), NOAA Air Resources Laboratory, Silver Spring, MD, 2003.

Drewnick, F., Hings, S. S., Alfarra, M. R., Prevot, A. S. H., and Borrmann, S.: Aerosol quantification with the Aerodyne Aerosol Mass Spectrometer: detection limits and ionizer background effects, Atmos. Meas. Tech., 2, 33-46, 2009.

Eerdekens, G., Yassaa, N., Sinha, V., Aalto, P. P., Aufmhoff, H., Arnold, F., Fiedler, V., Kulmala, M., and Williams, J.: VOC measurements within a boreal forest during spring 2005: on the occurrence of elevated monoterpene concentrations during night time intense particle concentration events, Atmos. Chem. Phys., 9, 8331-8350, 2009,

http://www.atmos-chem-phys.net/9/8331/2009/.

Ehn, M., Petäjä, T., Aufmhoff, H., Aalto, P., Hämeri, K., Arnold, F., Laaksonen, A., and Kulmala, M.: Hygroscopic properties of ultrafine aerosol particles in the boreal forest: diurnal variation, solubility and the influence of sulfuric acid, Atmos. Chem. Phys., 7, 211-222, 2007a, http://www.atmos-chem-phys.net/7/211/2007/.

Ehn, M., Petäjä, T., Birmili, W., Junninen, H., Aalto, P., and Kulmala, M.: Non-volatile residuals of newly formed atmospheric particles in the boreal forest, Atmos. Chem. Phys., 7, 677-684, 2007b, http://www.atmos-chem-phys.net/7/677/2007/. 
Gysel, M., Weingartner, E., Nyeki, S., Paulsen, D., Baltensperger, U., Galambos, I., and Kiss, G.: Hygroscopic properties of water-soluble matter and humic-like organics in atmospheric fine aerosol, Atmos. Chem. Phys., 4, 35-50, 2004,

http://www.atmos-chem-phys.net/4/35/2004/.

Gysel, M., Crosier, J., Topping, D. O., Whitehead, J. D., Bower, K. N., Cubison, M. J., Williams, P. I., Flynn, M. J., McFiggans, G. B., and Coe, H.: Closure study between chemical composition and hygroscopic growth of aerosol particles during TORCH2, Atmos. Chem. Phys., 7, 6131-6144, 2007,

http://www.atmos-chem-phys.net/7/6131/2007/.

Hämeri, K., Väkevä, M., Hansson, H.-C., and Laaksonen, A.: Hygroscopic growth of ultrafine ammonium sulphate aerosol measured using an ultrafine tandem differential mobility analyzer, J. Geophys. Res., 105, 22231-22242, doi:10.1029/2000JD900220, 2000.

Hämeri, K., Väkevä, M., Aalto, P. P., Kulmala, M., Swietlicki, E., Zhou, J., Seidl, W., Becker, E., and O'Dowd, C. D.: Hygroscopic and $\mathrm{CCN}$ properties of aerosol particles in boreal forests, Tellus B, 53, 359-379, 2001.

Hari, P. and Kulmala, M.: Station for Measuring Ecosystem - Atmosphere Relations (SMEAR II), Boreal Environ. Res., 10, 315$322,2005$.

Huffman, J. A., Docherty, K. S., Aiken, A. C., Cubison, M. J., Ulbrich, I. M., DeCarlo, P. F., Sueper, D., Jayne, J. T., Worsnop, D. R., Ziemann, P. J., and Jimenez, J. L.: Chemicallyresolved aerosol volatility measurements from two megacity field studies, Atmos. Chem. Phys., 9, 7161-7182, 2009,

http://www.atmos-chem-phys.net/9/7161/2009/.

Jayne, J., Leard, D., Zhang, X., Davidovits, P., Smith, K., Kolb, C., and Worsnop, D.: Development of an aerosol mass spectrometer for size and composition analysis of submicron particles, Aerosol Sci. Tech., 33, 49-70, 2000.

Jimenez, J., Jayne, J., Shi, Q., Kolb, C., Worsnop, D., Yourshaw, I., Seinfeld, J., Flagan, R., Zhang, X., Smith, K., Morris, J., and Davidovits, P.: Ambient aerosol sampling using the Aerodyne Aerosol Mass Spectrometer, J. Geophys. Res., 108, 8425, doi:10.1029/2001JD001213, 2003.

Jimenez, J. L., Canagaratna, M. R., Donahue, N. M., Prevot, A. S. H., Zhang, Q., Kroll, J. H., DeCarlo, P. F., Allan, J. D., Coe, H., Ng, N. L., Aiken, A. C., Docherty, K. S., Ulbrich, I. M., Grieshop, A. P., Robinson, A. L., Duplissy, J., Smith, J. D., Wilson, K. R., Lanz, V. A., Hueglin, C., Sun, Y. L., Tian, J., Laaksonen, A., Raatikainen, T., Rautiainen, J., Vaattovaara, P., Ehn, M., Kulmala, M., Tomlinson, J. M., Collins, D. R., Cubison, M. J., Dunlea, E. J., Huffman, J. A., Onasch, T. B., Alfarra, M. R., Williams, P. I., Bower, K., Kondo, Y., Schneider, J., Drewnick, F., Borrmann, S., Weimer, S., Demerjian, K., Salcedo, D., Cottrell, L., Griffin, R., Takami, A., Miyoshi, T., Hatakeyama, S., Shimono, A., Sun, J. Y., Zhang, Y. M., Dzepina, K., Kimmel, J. R., Sueper, D., Jayne, J. T., Herndon, S. C., Trimborn, A. M., Williams, L. R., Wood, E. C., Middlebrook, A. M., Kolb, C. E., Baltensperger, U., and Worsnop, D. R.: Evolution of organic aerosols in the atmosphere, Science, 326, 1525-1529, 2009.

Johnson, G. R., Ristovski, Z., and Morawska, L.: Method for measuring the hygroscopic behaviour of lower volatility fractions in an internally mixed aerosol, J. Aerosol Sci., 35, 443-455, 2004.

Joutsensaari, J., Vaattovaara, P., Vesterinen, M., Hämeri, K., and Laaksonen, A.: A novel tandem differential mobility analyzer with organic vapor treatment of aerosol particles, Atmos. Chem. Phys., 1, 51-60, 2001,

http://www.atmos-chem-phys.net/1/51/2001/.

Kalberer, M., Paulsen, D., Sax, M., Steinbacher, M., Dommen, J., Prevot, A. S. H., Fisseha, R., Weingartner, E., Frankevich, V., Zenobi, R., and Baltensperger, U.: Identification of polymers as major components of atmospheric organic aerosols, Science, 303, 1659-1662, 2004.

Kiendler-Scharr, A., Zhang, Q., Hohaus, T., Kleist, E., Mensah, A., Mentel, T. F., Spindler, C., Uerlings, R., Tillmann, R., and Wildt, J.: Aerosol Mass Spectrometric Features of Biogenic SOA: Observations from a plant chamber and in rural atmospheric environments, Environ. Sci. Technol., 43, 8166-8172, 2009.

Kourtchev, I., Ruuskanen, T., Maenhaut, W., Kulmala, M., and Claeys, M.: Observation of 2-methyltetrols and related photooxidation products of isoprene in boreal forest aerosols from Hyytiälä, Finland, Atmos. Chem. Phys., 5, 2761-2770, 2005, http://www.atmos-chem-phys.net/5/2761/2005/.

Kulmala, M., Hämeri, K., Aalto, P. P., Mäkelä, J. M., Pirjola, L., Nilsson, E. D., Buzorius, G., Rannik, Ü., Dal Maso, M., Seidl, W., Hoffman, T., Jansson, R., Hansson, H.-C., Viisanen, Y., Laaksonen, A., and O'Dowd, C. D.: Overview of the international project on biogenic aerosol formation in the boreal forest (BIOFOR), Tellus B, 53, 324-343, 2001.

Kulmala, M., Mordas, G., Petäjä, T., Grönholm, T., Aalto, P. P., Vehkamäki, H., Hienola, A. I., Herrmann, E., Sipilä, M., Riipinen, I., Manninen, H. E., Hämeri, K., Stratmann, F., Bilde, M., Winkler, P. M., Birmili, W., and Wagner, P. E.: The condensation particle counter battery (CPCB): A new tool to investigate the activation properties of nanoparticles, J. Aerosol Sci., 38, 289-304, 2007.

Kulmala, M., Kerminen, V.-M., Laaksonen, A., Riipinen, I., Sipilä, M., Ruuskanen, T. M., Sogacheva, L., Hari, P., Bäck, J., Lehtinen, K. E. J., Viisanen, Y., Bilde, M., Svenningson, B., Lazaridis, M., Tørseth, K., Tunved, P., Nilsson, E. D., Pryor, S., Sørensen, L.-L., Hõrrak, U., Winkler, P. M., Swietlicki, E., Riekola, M.-L., Krejci, R., Hoyle, C., Hov, Ø., Myhre, G., and Hansson, H.-C.: Overview of the biosphere-aerosol-cloudclimate interactions (BACCI) studies, Tellus B, 60, 300-317, 2008.

Lanz, V. A., Alfarra, M. R., Baltensperger, U., Buchmann, B., Hueglin, C., and Prévôt, A. S. H.: Source apportionment of submicron organic aerosols at an urban site by factor analytical modelling of aerosol mass spectra, Atmos. Chem. Phys., 7, 15031522, 2007,

http://www.atmos-chem-phys.net/7/1503/2007/.

Mäkelä, J. M., Yli-Koivisto, S., Hiltunen, V., Seidl, W., Swietlicki, E., Teinilä, K., Sillanpää, M., K., K., Paatero, J., Rosman, K., and Hämeri, K.: Chemical composition of aerosol during particle formation events in boreal forest, Tellus B, 53, 380393, 2001.

Ng, N. L., Canagaratna, M. R., Zhang, Q., Jimenez, J. L., Tian, J., Ulbrich, I. M., Kroll, J. H., Docherty, K. S., Chhabra, P. S., Bahreini, R., Murphy, S. M., Seinfeld, J. H., Hildebrandt, L., DeCarlo, P. F., Lanz, V. A., Prevot, A. S. H., Dinar, E., Rudich, Y., and Worsnop, D. R.: Organic aerosol components observed in worldwide datasets from aerosol mass spectrometry, Atmos. Chem. Phys. Discuss., 9, 27745-27789, 2009,

http://www.atmos-chem-phys-discuss.net/9/27745/2009/. 
Niemi, J. V., Saarikoski, S., Tervahattu, H., Mäkelä, T., Hillamo, R., Vehkamäki, H., Sogacheva, L., and Kulmala, M.: Changes in background aerosol composition in Finland during polluted and clean periods studied by TEM/EDX individual particle analysis, Atmos. Chem. Phys., 6, 5049-5066, 2006, http://www.atmos-chem-phys.net/6/5049/2006/.

O'Dowd, C. D., Becker, E., Mäkelä, J. M., and Kulmala, M.: Aerosol physico-chemical characteristics over a boreal forest determined by volatility analysis, Boreal Environ. Res., 5, 337348, 2000

Paatero, P. and Tapper, U.: Positive matrix factorization: A non-negative factor model with optimal utilization of error estimates of data values, Environmetrics, 5, 111-126, doi:10.1002/env.3170050203, 1994.

Paatero, P.: Least squares formulation of robust non-negative factor analysis, Chemom. Intell. Lab. Syst., 37, 23-35, 1997.

Petäjä, T., Kerminen, V.-M., Hämeri, K., Vaattovaara, P., Joutsensaari, J., Junkermann, W., Laaksonen, A., and Kulmala, M.: Effects of $\mathrm{SO}_{2}$ oxidation on ambient aerosol growth in water and ethanol vapours, Atmos. Chem. Phys., 5, 767-779, 2005, http://www.atmos-chem-phys.net/5/767/2005/.

Philippin, S., Wiedensohler, A., and Stratmann, F.: Measurements of non-volatile fractions of pollution aerosols with an eighttube volatility tandem differential mobility analyzer (VTDMA8), J. Aerosol Sci., 35, 185-203, 2004.

Prenni, A. J., DeMott, P. J., Kreidenweis, S. M., Sherman, D. E., Russell, L. M., and Ming, Y.: The effects of low molecular weight dicarboxylic acids on cloud formation, J. Phys. Chem. A, 37, 11240-11248, 2001.

Rader, D. and McMurry, P.: Application of the tandem differential mobility analyzer to studies of droplet growth or evaporation, J. Aerosol Sci., 17, 771-787, 1986.

Riipinen, I., Sihto, S.-L., Kulmala, M., Arnold, F., Dal Maso, M., Birmili, W., Saarnio, K., Teinilä, K., Kerminen, V.-M., Laaksonen, A., and Lehtinen, K. E. J.: Connections between atmospheric sulphuric acid and new particle formation during QUEST IIIIV campaigns in Heidelberg and Hyytiälä, Atmos. Chem. Phys., 7, 1899-1914, 2007,

http://www.atmos-chem-phys.net/7/1899/2007/.

Saarikoski, S., Mäkelä, T., Hillamo, R., Aalto, P. P., Kerminen, V.-M., and Kulmala, M.: Physico-chemical characterization and mass closure of size-segregated atmospheric aerosols in Hyytiälä, Finland, Boreal Environ. Res., 10, 385-400, 2005.

Saxena, P. and Hildemann, L. M.: Water-soluble organics in atmospheric particles: a critical review of the literature and application of thermodynamics to identify candidate compounds, J. Atmos. Chem., 24, 57-109, 1996.

Seinfeld, J. H. and Pandis, S. N.: Atmospheric chemistry and physics: from air pollution to climate change, John Wiley and Sons, Inc., New Jersey, USA, 2006.

Stokes, R. H. and Robinson, R. A.: Interactions in aqueous nonelectrolyte solutions. I. Solute-Solvent Equilibria, J. Phys. Chem., 70, 2126-2131, 1966.

Tarvainen, V., Hakola, H., Hellén, H., Bäck, J., Hari, P., and Kulmala, M.: Temperature and light dependence of the VOC emissions of Scots pine, Atmos. Chem. Phys., 5, 989-998, 2005, http://www.atmos-chem-phys.net/5/989/2005/.

Tiitta, P., Miettinen, P., Vaattovaara, P., Joutsensaari, J., Petäjä, T., Virtanen, A., Raatikainen, T., Aalto, P., Portin, H., Ro- makkaniemi, S., Kokkola, H., Lehtinen, K. E. J., Kulmala, M., and Laaksonen, A.: Roadside aerosol study using hygroscopic, organic and volatility TDMAs: Characterization and mixing state, Atmos. Environ., 44, 976-986, 2010.

Tunved, P., Hansson, H.-C., Kerminen, V.-M., Ström, J., Dal Maso, M., Lihavainen, H., Viisanen, Y., Aalto, P. P., Komppula, M., and Kulmala, M.: High natural aerosol loading over boreal forests, Science, 312, 261-263, 2006.

Ulbrich, I. M., Canagaratna, M. R., Zhang, Q., Worsnop, D. R., and Jimenez, J. L.: Interpretation of organic components from Positive Matrix Factorization of aerosol mass spectrometric data, Atmos. Chem. Phys., 9, 2891-2918, 2009, http://www.atmos-chem-phys.net/9/2891/2009/.

Vaattovaara, P., Räsänen, M., Kühn, T., Joutsensaari, J., and Laaksonen, A.: A method for detecting the presence of organic fraction in nucleation mode sized particles, Atmos. Chem. Phys., 5, 3277-3287, 2005, http://www.atmos-chem-phys.net/5/3277/2005/.

Vaattovaara, P., Petäjä, T., Joutsensaari, J., Miettinen, P., Zaprudin, B., Kortelainen, A., Heijari, J., Yli-Pirilä, P., Aalto, P., Worsnop, D. R., and Laaksonen, A.: The evolution of nucleationand Aitken-mode particle compositions in a boreal forest environment during clean and pollution-affected new-particle formation events, Boreal Environ. Res., 14, 662-682, 2009.

Varutbangkul, V., Brechtel, F. J., Bahreini, R., Ng, N. L., Keywood, M. D., Kroll, J. H., Flagan, R. C., Seinfeld, J. H., Lee, A., and Goldstein, A. H.: Hygroscopicity of secondary organic aerosols formed by oxidation of cycloalkenes, monoterpenes, sesquiterpenes, and related compounds, Atmos. Chem. Phys., 6, 23672388, 2006, http://www.atmos-chem-phys.net/6/2367/2006/.

Vesala, T., Haataja, J., Aalto, P., Altimir, N., Buzorius, G., Garam, E., Hämeri, K., Ilvesniemi, H., Jokinen, V., Keronen, P., Lahti, T., Markkanen, T., Mäkelä, J., E., N., Palmroth, S., Palva, L., Pohja, T., Pumpanen, J., Rannik, Ü., Siivola, E., Ylitalo, H., Hari, P., and Kulmala, M.: Long-term field measurements of atmosphere-surface interaction in boreal forest combining forest ecology, micrometeorology, aerosol physics and atmospheric chemistry, Trends in Heat, Mass and Momentum Transfer, 4, 17-35, 1998.

Villani, P., Picard, D., Marchand, N., and Laj, P.: Design and Validation of a 6-Volatility Tandem Differential Mobility Analyzer (VTDMA), Aerosol Sci. Tech., 41, 898-906, 2007.

Zhang, Q., Alfarra, M., Worsnop, D., Allan, J., Coe, H., Canagaratna, M., and Jimenez, J.: Deconvolution and Quantification of Hydrocarbon-like and Oxygenated Organic Aerosols Based on Aerosol Mass Spectrometry, Environ. Sci. Technol., 39, 49384952, 2005.

Zhang, Q., Jimenez, J., Canagaratna, M., Allan, J., Coe, H., Ulbrich, I., Alfarra, M., Takami, A., Middlebrook, A., Sun, Y., Dzepina, K., Dunlea, E., Docherty, K., DeCarlo, P., Salcedo, D., Onasch, T., Jayne, J., Miyoshi, T., Shimono, A., Hatakeyama, S., Takegawa, N., Kondo, Y., Schneider, J., Drewnick, F., Borrmann, S., Weimer, S., Demerjian, K., Williams, P., Bower, K., Bahreini, R., Cottrell, L., Griffin, R., Rautiainen, J., Sun, J., Zhang, Y., and Worsnop, D.: Ubiquity and dominance of oxygenated species in organic aerosols in anthropogenically-influenced Northern Hemisphere midlatitudes, Geophys. Res. Lett., 34, L13801, doi:10.1029/2007GL029979, 2007. 